\title{
Suppression of reproduction in Atlantic cod Gadus morhua
}

\author{
Rick M. Rideout ${ }^{1,2, *}$, George A. Rose $^{1}$ \\ ${ }^{1}$ Fisheries Conservation Group, Fisheries and Marine Institute, Memorial University of Newfoundland, PO Box 4920 , \\ St. John's, Newfoundland A1C 5R3, Canada \\ ${ }^{2}$ Present address: Department of Fisheries and Oceans, PO Box 5667, St. John's, Newfoundland A1C 5X1, Canada
}

\begin{abstract}
We explored the frequency of suppressed reproduction in Atlantic cod Gadus morhua in Smith Sound, Trinity Bay (NAFO Area 3L), Newfoundland, Canada, the largest remaining spawning aggregation of the so-called 'northern cod'. In the years 1999 to 2004, suppression of reproduction via mass atresia of vitellogenic oocytes occurred in 8.4 to $55.6 \%$ of potential female spawners. Suppression of reproduction was particularly common in the 40 to $49 \mathrm{~cm}$ size class, perhaps representing females aborting their first attempt at spawning, but was also common in all larger size classes, suggesting that spawning was not annual for all fish. The fact that non-reproductive fish were generally in poorer condition than those that were successfully ripening suggests a nutritional control to spawning. Stable isotope $\left(\delta^{13} \mathrm{C}\right)$ signatures suggest that small to medium sized cod $(40$ to $60 \mathrm{~cm})$ were more likely to spawn when feeding on pelagic (i.e. capelin) than benthic (i.e. shrimp) prey. Small to medium sized cod in Smith Sound were generally in poorer nutritional condition than those in nearby Placentia Bay. Stomach content analysis suggested that Placentia Bay cod fed more heavily on capelin than those in Smith Sound and that they fed year-round, whereas Smith Sound cod ceased feeding during winter. Years with the highest degree of reproductive suppression in Smith Sound were also the years with the highest proportion of female fish in the 40 to $49 \mathrm{~cm}$ size class, suggesting that yearly variability in the number of non-reproductive fish was related to population size structure. Failure to account for the non-reproductive portion of the population resulted in overestimation of egg production by 8 to $41 \%$ annually for the Smith Sound aggregation. The results emphasise the need to adjust spawning stock biomass accordingly in order to accurately estimate reproductive potential in marine groundfish and develop effective management strategies.
\end{abstract}

KEY WORDS: Atlantic cod · Gadus morhua - Spawning $\cdot$ Reproduction $\cdot$ Reproductive potential Resale or republication not permitted without written consent of the publisher

\section{INTRODUCTION}

The high degree of variability inherent to stockrecruitment relationships has raised questions about the adequacy of spawning stock biomass (SSB) as an estimator of reproductive potential for marine groundfish and caused some to explore alternative indices of reproductive potential for use in fisheries management (Marshall et al. 2003). The shortfall of SSB as a predictor of recruitment may partly result from difficulties in accurately estimating the true number of spawners in an aggregation. For example, experimental data on a range of marine, freshwater and anadromous fishes suggest that unsuitable environmental conditions can cause fishes to suppress gamete production, preventing them from spawning (reviewed by Rideout et al. 2005). Suppression of reproduction in fishes can occur either by failing to start vitellogenesis or by starting and subsequently interrupting vitellogenesis by mass atresia of all vitellogenic oocytes (Rideout et al. 2005). These interruptions to the normal spawning cycle can occur in both recruit- and repeat-spawning individuals. In the latter case, suppression of reproduction results in non-annual or skipped spawning. Failure to recognise these interruptions in gamete development for both recruit- and repeat-spawning individuals can 
lead to inaccurate estimates of population egg production and overestimates of reproductive potential.

Suppression of reproduction appears to be frequent in fishes living in northern lakes with a short growing season (Kennedy 1953, Dutil 1986), as well as SW Pacific orange roughy Hoplostethus atlanticus (Bell et al. 1992) and Norwegian spring-spawning herring Clupea harengus (Engelhard \& Heino 2005). In the Northwest Atlantic, suppression of reproduction is common among Flemish Cap cod Gadus morhua (Walsh et al. 1986). Very little attention, however, has been directed at determining the frequency of suppressed reproduction in other NW Atlantic groundfish stocks.

We explored the frequency of suppressed reproduction in Smith Sound (see Fig. 1) Atlantic cod, the largest remaining spawning aggregation of the northern cod stock complex (Northwestern Atlantic Fisheries Organization [NAFO] Division 2J3KL) (Rose 2003). Intermittent sampling has suggested that some degree of reproductive suppression occurs in the sound (Brattey 1996, Rideout et al. 2000), but the yearly extent is uncertain. The objectives of the present study were to (1) estimate the frequency of suppressed reproduction in the Smith Sound aggregation over a 6 yr period (1999 to 2004), (2) compare biological characteristics (length, weight, condition, diet) of cod from Smith Sound with those from nearby Placentia Bay (where there have been no reports of suppressed cod reproduction) in order to examine potential causes of reproductive suppression, and (3) to explore the consequences of suppressed reproduction with respect to population egg production. immature if ovaries were small and pink, ripening if opaque oocytes were visible, and spent-L (sensu Templeman et al. 1978) if ovaries were small and red with no opaque eggs (see Fig. 2 in Rideout et al. 2005). In 1999, histological examination of the ovaries of 150 of the fish sampled revealed that over $70 \%$ of these females were undergoing mass atresia of all oocytes that had commenced vitellogenesis and therefore would not have spawned in the forthcoming spawning season (Rideout et al. 2000). Therefore, spent-L ovaries collected at this time of the year were considered to be reproductively suppressed and not capable of spawning. Likewise, Walsh et al. (1986) histologically confirmed that spent-L Flemish Cap cod collected in January or February were not capable of spawning. Previously, mature fish that fail to spawn have been referred to as 'postmature non-reproductive' (Burton \& Idler 1984). Here we simply use 'non-reproductive' to refer to all fish with suppressed gamete development since, without the use of histology, it is impossible to distinguish between females that are aborting their first attempt at spawning and those that have spawned in previous years but are aborting their most recent spawning attempt. For our purposes, distinguishing between these 2 groups of females was deemed unnecessary since both were viewed as 'potential spawners' (i.e. both had started to ripen) that would not spawn. The proportion of non-reproductive fish in Smith Sound was compared between years.

Condition factors based on whole weight $\left(K_{\mathrm{W}}\right)$ and somatic (gutted) weight $\left(K_{\mathrm{S}}\right)$ were calculated as $K_{\mathrm{W}}=W_{\mathrm{W}} / L^{3} \times 100$ and $K_{\mathrm{S}}=W_{\mathrm{S}} / L^{3} \times 100$, where $W_{\mathrm{W}}$

\section{MATERIALS AND METHODS}

Fish collection. A total of 3991 female cod Gadus morhua were sampled over a $6 \mathrm{yr}$ period (1999 to 2004) from Smith Sound and other nearby areas in NAFO Area 3L using a Campelen 1800 shrimp trawl fitted with a small mesh liner. Sampling concentrated heavily on Smith Sound (Fig. 1), where $91.9 \%$ of the reproductive sized fish $(\geq 40 \mathrm{~cm})$ were collected. Cod were sampled in January in the years 1999 to 2003 and in February in 2004.

Baseline data collected on all fish included fork length, whole weight, somatic or gutted weight (whole weight minus viscera weight), liver weight and gonad weight. Otoliths were removed for later aging. The reproductive status of all fish was determined via macroscopic inspection of the ovaries. Females were classified as

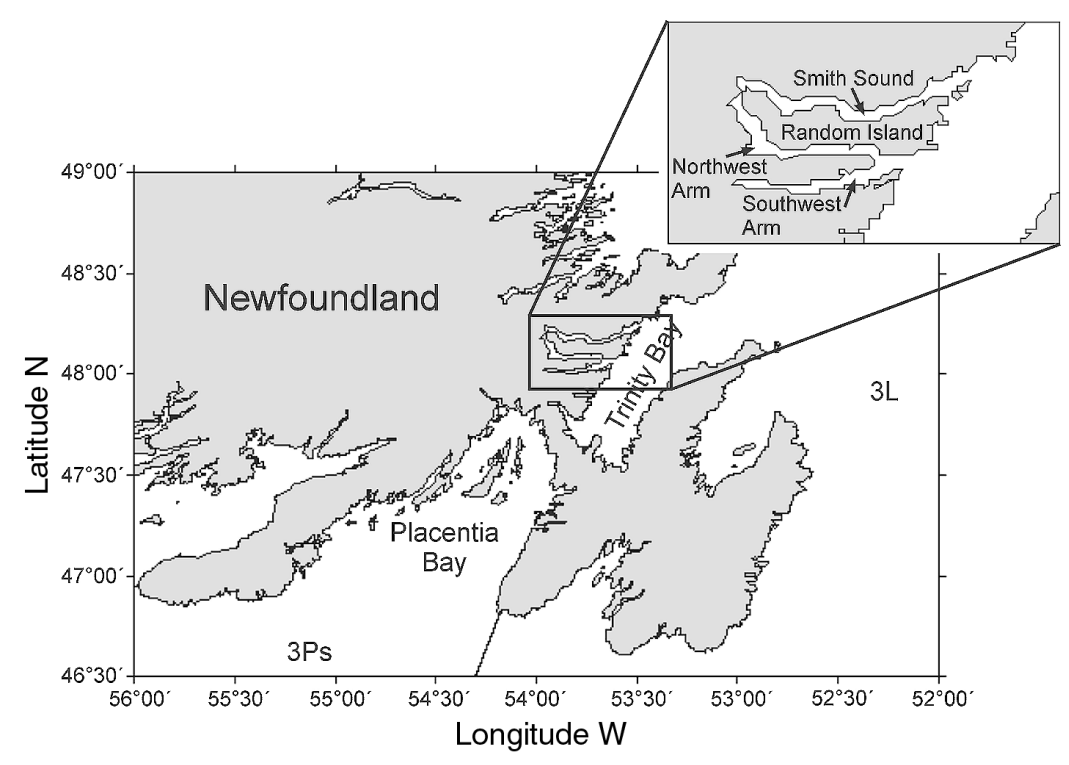

Fig. 1. Study areas at Smith Sound (in NAFO Division 3L) and Placentia Bay (in NAFO subdivision 3Ps), Newfoundland 
represents whole weight $(\mathrm{g}), W_{\mathrm{S}}$ represents somatic weight $(\mathrm{g})$ and $L$ represents fork length $(\mathrm{cm})$. Liver somatic index (LSI) and gonadosomatic index (GSI) were calculated as LSI $=W_{\mathrm{L}} / W_{\mathrm{S}} \times 100$ and GSI $=W_{\mathrm{G}} / W_{\mathrm{S}}$ $\times 100$, where $W_{\mathrm{L}}$ represents liver weight $(\mathrm{g})$ and $W_{\mathrm{G}}$ represents gonad weight $(\mathrm{g})$. Condition indices were compared between years, between fish of different reproductive status, and between fish from Smith Sound and Placentia Bay.

Stomach content analysis. A cod stomach content database that contains information on both Smith Sound (Area 3L) and Placentia Bay (Area 3Ps) cod was used to compare diet between fish from the 2 areas. We used data from cod collected in both January (3L $\mathrm{n}=3694 ; 3$ Ps $\mathrm{n}=732$ ) and June (3L $\mathrm{n}=2060 ; 3 \mathrm{Ps}$ $\mathrm{n}=1881$ ). The prey categories used were capelin, cod, sand lance, herring, zooplankton (pooled taxa, including amphipods, euphausiids, hyperiids, isopods and mysids), squid, crab (primarily snow crab Chionoecetes opilio), invertebrates, benthos (primary brittle stars and polychaetes), cod, shrimp (primarily northern shrimp Pandalus borealis), other gadoids (such as rock cod Gadus ogac and arctic cod Boreogadus saida) and other fishes (includes redfish, flatfishes, sculpins, grenadiers, alligatorfish and blennies). The relative importance of each prey category was determined using indices of stomach fullness. The mean partial fullness index (Fahrig et al. 1993) for prey $i\left(\mathrm{PFI}_{i}\right)$ was calculated as:

$$
\text { mean } \mathrm{PFI}_{i}=\frac{1}{n} \sum_{j=1}^{n} \frac{W_{i j}}{L_{j}^{3}} \times 10^{4}
$$

where $W_{i j}$ is the weight of Prey $i$ in Fish $j_{1} L_{j}$ is the fork length of Fish $j$, and $n$ is the total number of fish in the sample. Mean total fullness index (TFI) was calculated in the same manner using the total weight of stomach contents for each fish. Partial and total fullness indices were compared between Smith Sound and Placentia Bay cod in both January and June.

Stable carbon isotope analysis. For 30 females between 40 and $60 \mathrm{~cm}$ in length collected from Smith Sound in February 2004, a small sample of dorsal white muscle was excised from immediately posterior to the head and frozen at $-20^{\circ} \mathrm{C}$ in $1.5 \mathrm{ml}$ microcentrifuge tubes. Frozen muscle samples were thawed and dried for $48 \mathrm{~h}$ at 70 to $75^{\circ} \mathrm{C}$ in a drying oven and crushed to a fine powder using a mortar and pestle. Powdered samples were analysed for stable carbon isotopes by G. G. Hatch Isotope Laboratories at the University of Ottawa. Weighed subsamples of the dried, powdered material were combusted in tin capsules on a CE1110 elemental analyser. The resulting gases were carried by helium through a gas chromatograph column for separation, then into a Thermo Finnigan Deltaplus Advantage isotope ratio mass spectrometer for iso- topic analysis via a ConFlo interface. Stable carbon isotope ratios were expressed as:

$$
\delta^{13} \mathrm{C}=\left(\frac{R_{\text {sample }}}{R_{\text {standard }}}-1\right) \times 1000
$$

where $R={ }^{13} \mathrm{C}:{ }^{12} \mathrm{C}$ and standard is material equivalent to Pee Dee belemnite limestone. Stable isotope data were used to compare the feeding history of spawning and non-spawning individuals from Smith Sound.

Data analysis. The number of fish with suppressed reproduction (spent-L) was expressed as a proportion of the number of potential spawners (i.e. ripening and spent-L). The relationships between mean bottom temperature and fish condition at the time of capture and the yearly proportion of fish with suppressed reproduction was explored using linear regression. Condition indices were compared (by $10 \mathrm{~cm}$ size classes) between reproductive stages of development (immature, ripening, spent-L) using analysis of variance (ANOVA, Tukey's HSD). $\delta^{13} \mathrm{C}$ signatures tend to increase with increasing fish length (Sherwood \& Rose 2005) and were therefore compared between ripening and non-ripening (immature and spent-L) females using analysis of covariance (ANCOVA) with fork length as covariate. Stomach fullness indices were compared between Smith Sound and Placentia Bay fish using analysis of variance (ANOVA). Assumptions of normality and heterogeneity of variances were met for all tests.

Population egg production. In order to determine the effects of suppressed reproduction on reproductive potential, we produced yearly estimates of population egg production based on (1) all fish that started to ripen (i.e. no suppression) and (2) only fish that would have completed ripening and spawned successfully (i.e. SSB adjusted for observed levels of suppressed reproduction). Acoustic-trawl survey estimates of the number of fish per size class (Rose 2003) were divided in half in order to estimate the number of females in the aggregation. Fecundities at length from May (1967) were multiplied by the number of females per size class in order to determine the total contribution of all females of that size group to the aggregation's total egg production.

\section{RESULTS}

Suppression of reproduction is common in cod in Smith Sound, with a portion of females examined in all 6 yr of the study (1999 to 2004) beginning to ripen but subsequently undergoing atresia of all vitellogenic oocytes (Fig. 2). The frequency of non-reproductive fish varied from $<10$ to $55 \%$, peaked in 1999 and 2003, and was lowest in 2001. Yearly variation in the propor- 


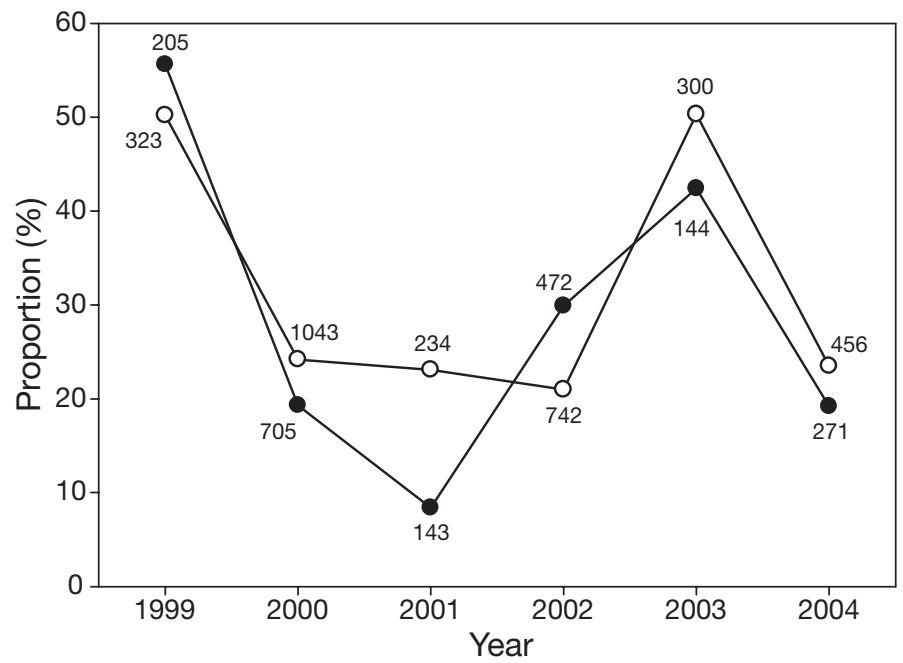

Fig. 2. Gadus morhua. Proportion of potential spawning females in Smith Sound that suppressed gamete development in the years 1999 to 2004 (•) and proportion of potential spawners in 40 to $49 \mathrm{~cm}$ size class (०). Sample sizes indicated

tion of non-reproductive females was not related to mean bottom temperature $(p=0.789)$ or mean fish condition ( $p=0.209)$ at the time of capture (although with only 6 data points, these analyses had little power). Unfortunately data are not available to repeat the analyses for Smith Sound at other times of the year.

Suppression of reproduction was most common in the 40 to $49 \mathrm{~cm}$ size class (Fig. 3), corresponding to 4 yr old fish (Fig. 4). The yearly variability in the proportion of females in the 40 to $49 \mathrm{~cm}$ size range in Smith Sound followed roughly the pattern in the

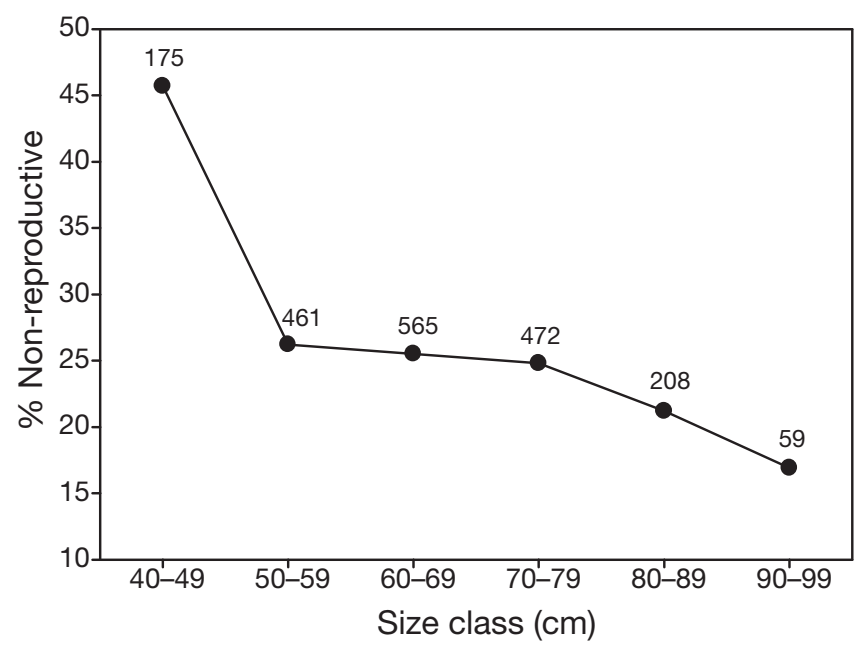

Fig. 3. Gadus morhua. Proportion of potential spawning females in each $10 \mathrm{~cm}$ size class in Smith Sound that had suppressed reproduction at the time of sampling (January or February). Combined data for 1999 to 2004. Sample sizes indicated

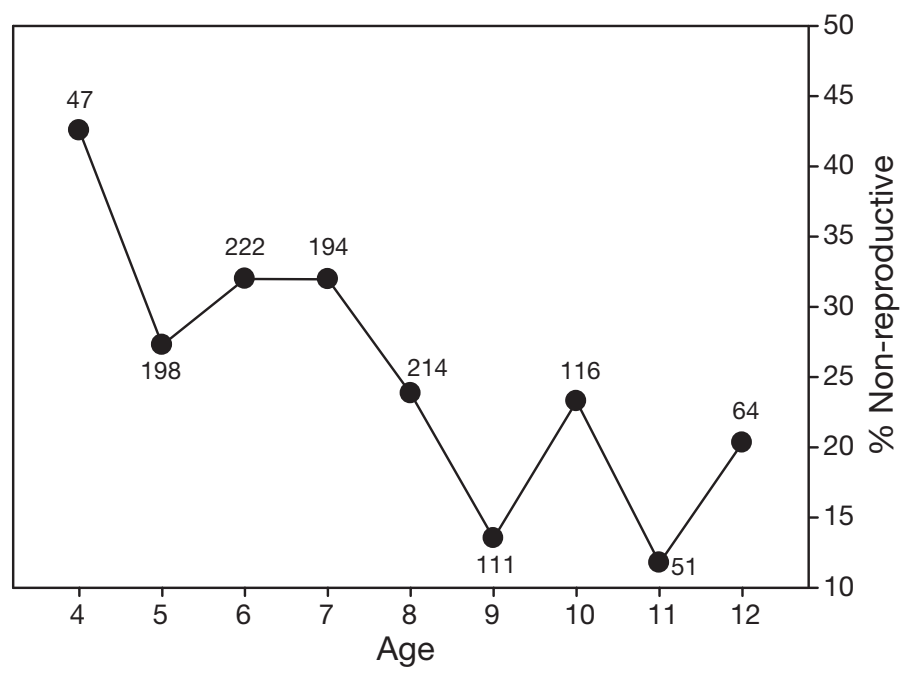

Fig. 4. Gadus morhua. Proportion of potential spawning females as a function of age in Smith Sound that had suppressed reproduction at the time of sampling (January or February). Combined data for 1999 to 2004. Sample sizes indicated

yearly proportion of females with suppressed reproduction, with maximum values occurring in 1999 and 2003 (Fig. 2). Although most prevalent in the smaller size classes, suppression of reproduction was common in all size categories $\geq 40 \mathrm{~cm}$ (Fig. 3), and the proportion of spawning fish in any size class never reached $100 \%$ (Fig. 5)

Indices of condition at the time of capture were significantly lower $(p<0.05)$ for non-reproductive females than for ripening females throughout the size range of fish sampled, with the exception $(p=0.649)$ of the 40 to

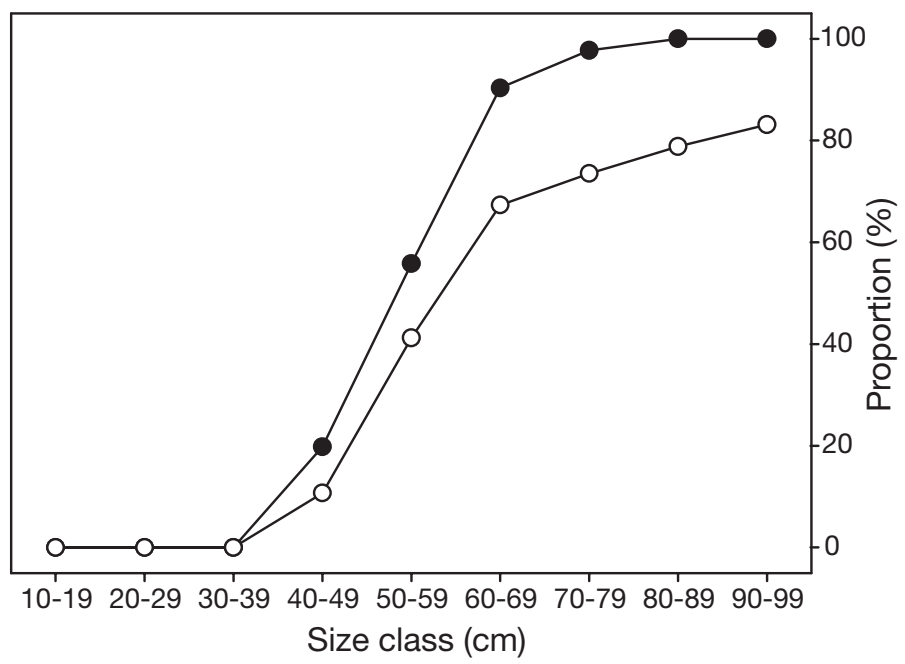

Fig. 5. Gadus morhua. Proportion of females that were adults (O) compared to proportion that would actually have spawned (O). Pooled data for 1999 to 2003 

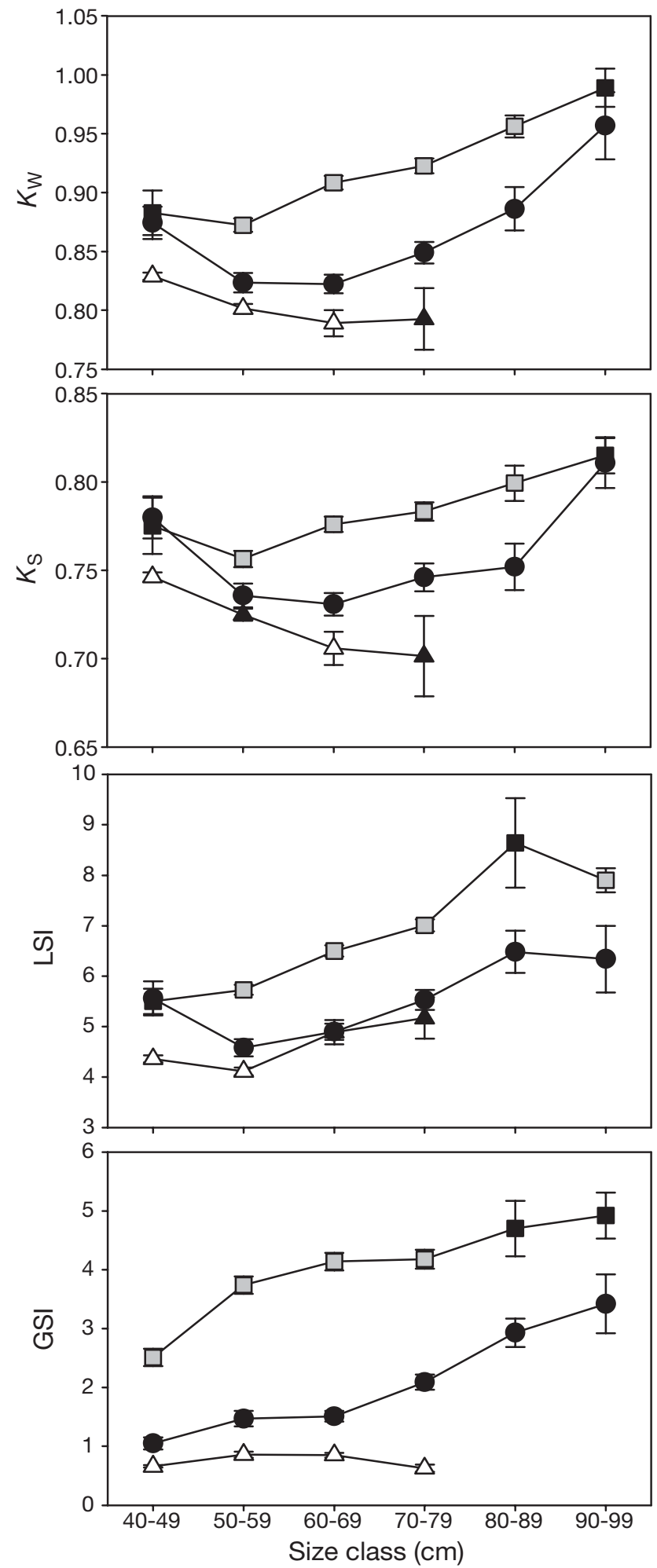

Fig. 6. Gadus morhua. Mean $( \pm 1$ SE) condition indices for immature $(\Delta, \boldsymbol{\Delta})$, ripening $(\square, \boldsymbol{\square})$ and reproductively suppressed (-) females in Smith Sound in January. Combined data for 1999 to 2004. Symbols within same size class that have different shading indicate significant difference among the stages of reproductive development

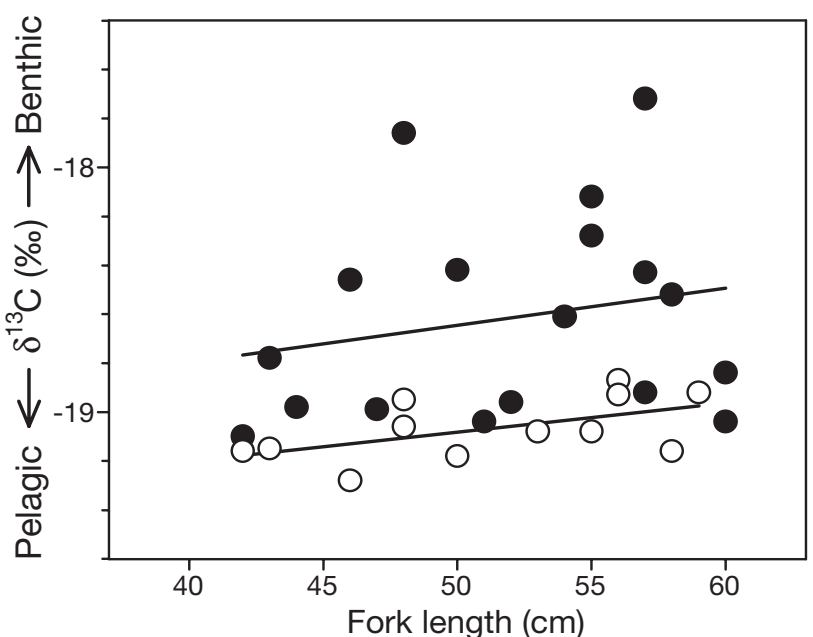

Fig. 7. Gadus morhua. Individual $\delta^{13} \mathrm{C}$ signatures for female cod in 40 to $60 \mathrm{~cm}$ size range in Smith Sound in January 2004. (O) females that would have spawned; (O) females that would not have spawned (i.e. immature and those with suppressed gamete development). Lines $=$ best-fit linear regressions

$49 \mathrm{~cm}$ size class (Fig. 6). Analysis of $\delta^{13} \mathrm{C}$ signatures (Fig. 7) revealed that female cod in the 40 to $60 \mathrm{~cm}$ size class that were successfully ripening (and presumably would have spawned) had lower $(\mathrm{p}=0.001) \delta^{13} \mathrm{C}$ signatures than individuals that were not successfully ripening (and therefore would not have spawned). There was a general tendency for GSI to increase with fish size (Table 1, Fig 6) and GSI was higher in ripening than non-reproductive individuals (Fig. 6)

Smith Sound female cod start ripening at a slightly smaller body size than do females in Placentia Bay (Fig. 8). However, females in these smaller size classes

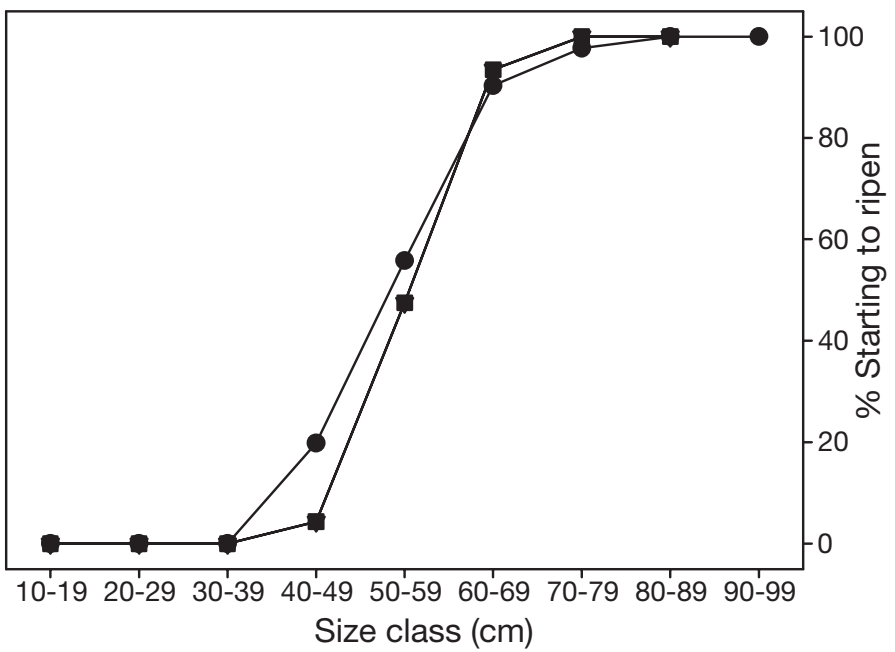

Fig. 8. Gadus morhua. Proportion of females in each $10 \mathrm{~cm}$ size class that had started to ripen by January or February in NAFO Areas 3L ( including Smith Sound) and 3Ps $(\mathrm{O}$; including Placentia Bay) 

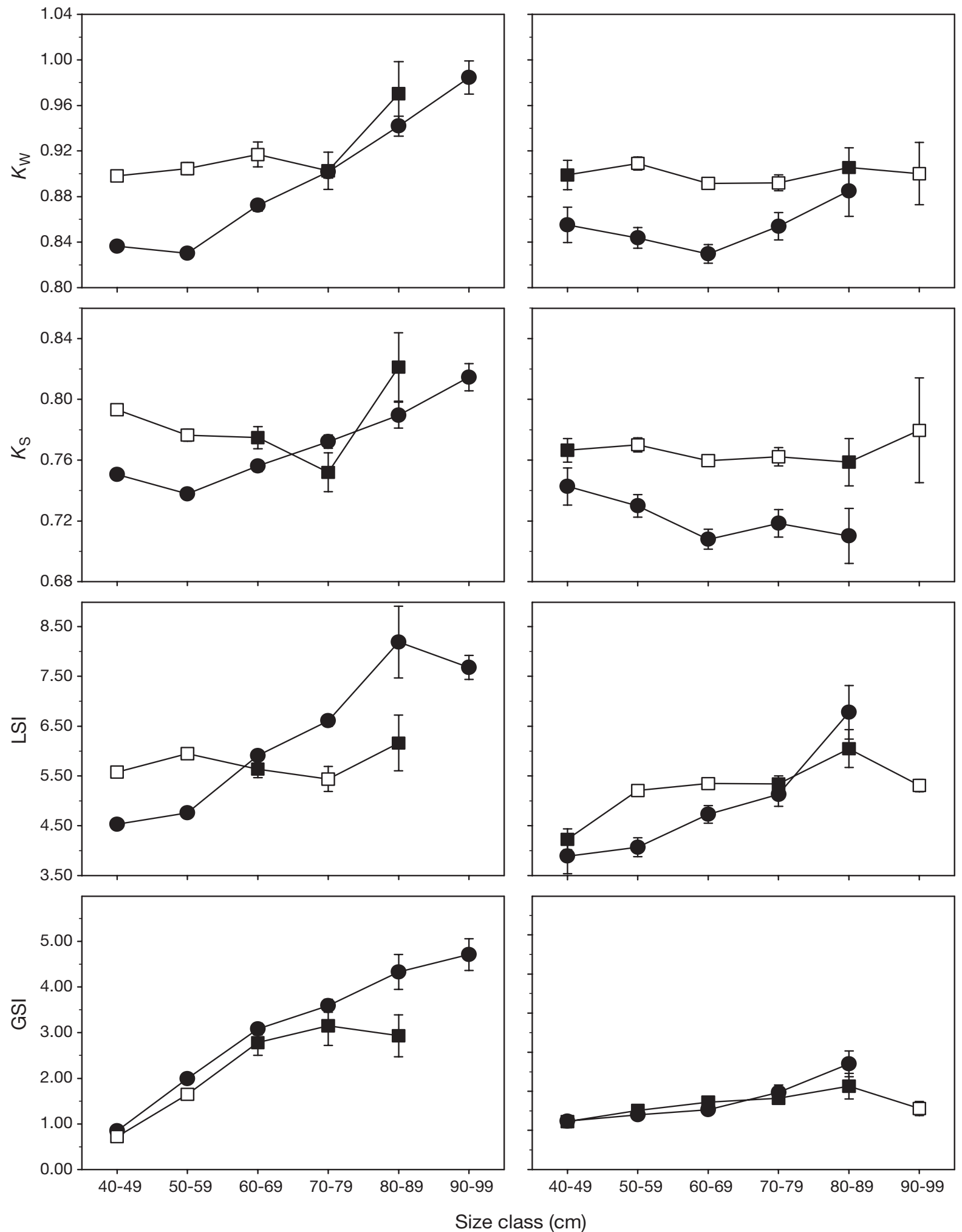

Fig. 9. Gadus morhua. Comparison of condition indices (mean \pm 1 SE) for female cod from NAFO Areas 3L ( Sound) and 3Ps $(\square, \mathbf{\square}$; including Placentia Bay). Graphs on left: indices for females of all maturity stages collected in January; graphs on right: indices for all spent females collected (regardless of sampling time). Combined data for 1999 to 2004 . Symbols within same size class that have different shading indicate significant difference between areas. $K_{\mathrm{W}}$ : whole weight; $K_{\mathrm{S}}$ : somatic (gutted) weight 
Table 1. Gadus morhua. Mean ( $\pm 1 \mathrm{SE}$ ) gonadosomatic index (GSI) for each $10 \mathrm{~cm}$ size class and year for cod in Smith Sound in the years 1999 to 2004. Sample sizes indicated in parentheses

\begin{tabular}{|lcccccc|}
\hline Size class & 1999 & \multicolumn{2}{c}{2000} & \multicolumn{2}{c}{2001} & \multicolumn{2}{c}{2002} & 2003 & 2004 \\
\hline $40-49$ & $1.43 \pm 1.37(57)$ & $1.19 \pm 0.67(34)$ & $1.94 \pm 0.72(9)$ & $2.50 \pm 1.27(29)$ & $2.43 \pm 1.05(33)$ & $2.86 \pm 1.57(13)$ \\
$50-59$ & $2.43 \pm 1.83(85)$ & $3.51 \pm 2.21(141)$ & $3.41 \pm 2.21(28)$ & $2.74 \pm 1.60(112)$ & $3.20 \pm 2.51(51)$ & $3.67 \pm 2.72(44)$ \\
$60-69$ & $3.06 \pm 1.63(44)$ & $3.59 \pm 2.28(238)$ & $4.39 \pm 2.96(66)$ & $3.18 \pm 1.99(114)$ & $1.97 \pm 1.34(41)$ & $3.39 \pm 2.86(62)$ \\
$70-79$ & $3.56 \pm 2.28(17)$ & $3.30 \pm 1.87(216)$ & $4.53 \pm 2.71(38)$ & $3.30 \pm 1.39(121)$ & $4.26 \pm 3.09(10)$ & $4.16 \pm 3.35(70)$ \\
$80-89$ & $2.91 \pm 0.82(2)$ & $3.75 \pm 1.56(62)$ & $3.71 \pm 2.04(10)$ & $3.35 \pm 0.69(75)$ & $3.78 \pm 1.41(6)$ & $5.64 \pm 7.28(53)$ \\
$90-99$ & - & $2.97 \pm 1.27(6)$ & $4.94(1)$ & $4.20 \pm 1.62(19)$ & $8.07 \pm 6.65(3)$ & $4.66 \pm 1.41(30)$ \\
\hline
\end{tabular}

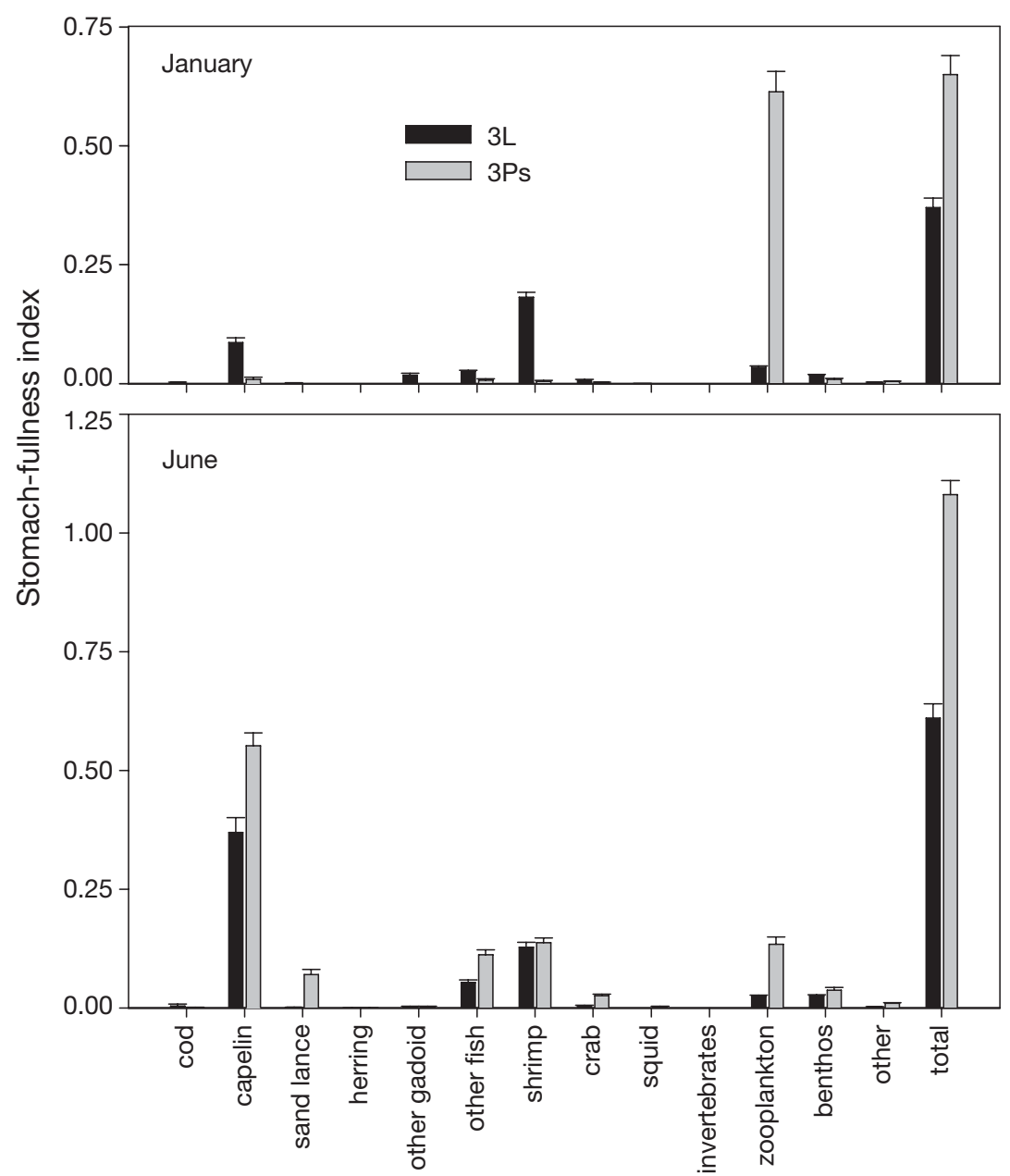

Fig. 10. Gadus morhua. Mean ( $\pm 1 \mathrm{SE})$ Partial and total stomach fullness indices for cod from NAFO Areas 3L and 3Ps in January and June
Sound as for those in Placentia Bay, driven primarily by winter feeding on zooplankton. In June, mean TFI was $77 \%$ higher in Placentia Bay than Smith Sound. $\mathrm{PFI}_{\text {capelin }}$ of Placentia Bay cod in June was $50 \%$ higher than in those from Smith Sound. This difference rose to nearly $70 \%$ if capelin and sand lance were grouped together.

The total number of eggs spawned each year in Smith Sound was less than the total predicted based on all fish that started to ripen (Fig. 11). The yearly reduction in egg production was dependent on both the number and size of non-reproductive fish and varied from $8 \%$ in 2001 to $41 \%$ in 2003 .

\section{DISCUSSION}

Reproduction was suppressed in a significant proportion of the Smith Sound cod population in 6 consecutive years, confirming that the high degree of suppression observed in Smith Sound in 1999 (Rideout et al. 2000) is not abnormal for the area, at least in contemporary times. Detailed data on the reproductive status of cod in Smith Sound are not available for the period prior to 1999. However, Brattey (1996) reported that some large $(>60 \mathrm{~cm})$ fish in Smith Sound $(9.8 \%)$ and nearby Southwest Arm (34.0\%) and Northwest Arm (8.5\%) had small, immature-looking ovaries in 1995, suggesting that suppression of reproduction may have been occurring in the area prior to 1999. Reports of suppressed reproduction have been made previously for cod from the NW Atlantic (Burton et al. 1997, Rideout et al. 2000) and the Baltic (Shirokova 1969) and Barents (Woodhead \& Woodhead 1965, Oganesyan 1993) Seas, but for the most part, these have been single place and time observations. Walsh et al.'s (1986) find-
Sound and Placentia Bay (Fig. 10). Mean TFI in January, however, was almost twice as high for cod in Smith from Smith Sound are in poorer condition than those Placentia Bay in January and February (Fig. 9). In range, are in poorer condition $(p<0.05)$ follow spawning than are Placentia Bay cod (Fig. 9).

Analysis of stomach contents showed a general reduction in stomach fullness for fish sampled in January versus those collected in June for both Smith 

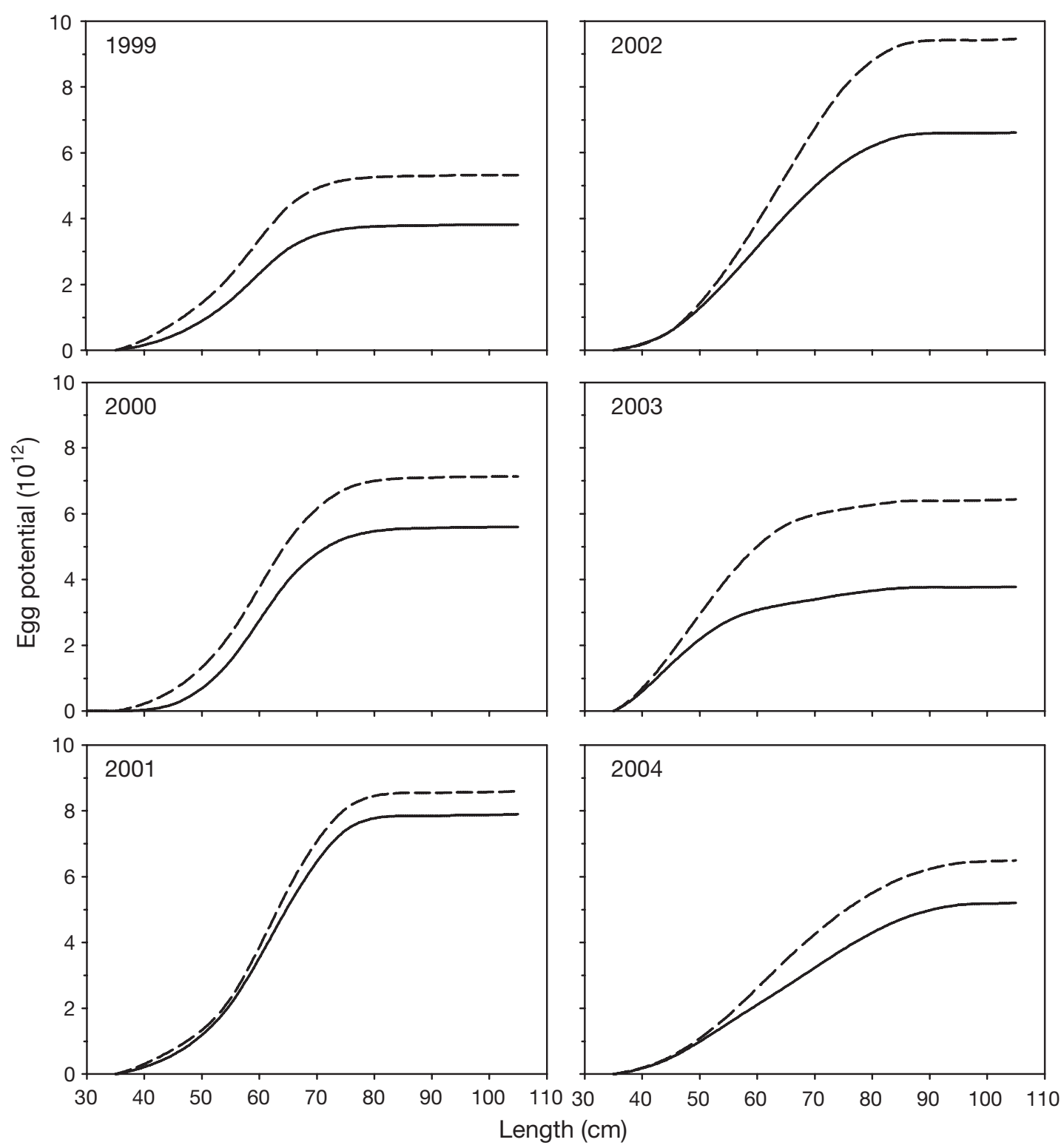

Fig. 11. Gadus morhua. Estimates of cumulative egg production potential as a function of fish length for cod from Smith Sound in 1999 to 2004. Estimates based on numbers of females that started to ripen (dashed line) and those that would have completed ripening and spawned (continuous line)

ings for Flemish Cap cod were very similar to those reported here, with reproduction being suppressed in 14 to $51 \%$ of female cod in the years 1978 to 1985 .

Suppression of reproduction in fishes occurs in response to the life-long trade-off between reproduction and survival. From an evolutionary point of view, an individual's fitness is positively related to its ability to survive and produce progeny. However, reproduction is very energetically demanding and investing too much energy into reproduction in any given year can increase the probability of post-spawning mortality (Lambert \& Dutil 2000). Therefore, suppressing reproduction in times of poor nutritional condition can increase an individual's likelihood of surviving to spawn in multiple subsequent years. The longer the reproductive lifespan of a species, the more likely it is to suppress reproduction in times of poor condition (Rideout et al. 2005). In long-lived species such as Atlantic cod, suppressing reproduction when energy reserves are such that spawning may compromise survival can actually increase lifetime reproductive output (Rideout et al. 2005).

For Smith Sound cod, failure to account for the nonspawning portion of the aggregation resulted in overestimation of total egg production by 8 to $41 \%$ annually. Such overestimates of the true spawner biomass 
can complicate the relationship between SSB and recruitment and make it difficult to implement effective management strategies. For example, Burton (1999) reported that the non-significant stock recruitment relationships for North Sea plaice and Area 2 Pacific halibut became significant if SSB was adjusted to account for the non-spawning portion of the adult population.

Suppression of reproduction in Smith Sound cod appears to be induced through diet restriction. At the time of capture, non-reproductive fish were in significantly poorer condition than those that were successfully ripening, suggesting that they had experienced reduced feeding success. Similar reports have been made for other species (Burton \& Idler 1984), and fish have been forced into a non-reproductive state through diet restriction in captivity (Hislop et al. 1978, Burton \& Idler 1987, Rijnsdorp 1990, Maddock \& Burton 1994). Kjesbu et al. (1991) reported that the intensity of atresia of developing oocytes in groups of cod fed at 4 ration levels was inversely related to fish nutritional status and caused the actual fecundity to be reduced by 20 to $80 \%$ of the potential fecundity. Here we have extended this to show that atresia of vitellogenic oocytes can in fact reduce fecundity to 0 (i.e. failure to spawn). Capelin is a lipid-rich diet and the preferred prey of cod around Newfoundland and Labrador (Lilly 1991), particularly for medium-sized fish (40 to $60 \mathrm{~cm}$ in length; Sherwood \& Rose in press). Our analysis of stable isotope data revealed that medium-sized cod that would spawn had lower $\delta^{13} \mathrm{C}$ signatures (indicative of feeding on pelagic prey; Sherwood \& Rose 2005) than those that would not, suggesting that capelin is particularly important for fuelling reproductive development. High proportions of nonspawning cod in areas or years with reduced capelin abundance have been used previously to suggest a link between capelin availability and cod spawning success (Oganesyan 1993, Marshall et al. 1998), and availability of capelin has been linked to cod fecundity at length (Kjesbu et al. 1998), liver condition (Yaragina \& Marshall 2000), growth rate (Steinarsson \& Stefánsson 1991, Ozhigin et al. 1994, Taggart et al. 1994, Steinarsson \& Stefánsson 1996) and weight at age (Ozhigin et al. 1994).

Examination of stomach contents suggests that feeding conditions between 1999 and 2004 were less favourable for cod in Smith Sound than in Placentia Bay. The partial fullness index of capelin and the total stomach fullness index were both higher for cod in Placentia Bay in June. Rose \& O'Driscoll (2002) also demonstrated that capelin availability to cod in Smith Sound was less than in Placentia Bay, but much greater than to cod on the northern bank. In addition, we found that stomach fullness indices for cod collected from Placentia Bay in January were higher than those for cod from Smith Sound, suggesting that Placentia Bay fish feed more during winter, primarily on zooplankton. That being said, we are not suggesting that suppression of reproduction does not occur in Placentia Bay, merely that it has not been reported. We believe that an increase in research on this subject will reveal that suppression of reproduction is a widespread phenomenon that may impact the reproductive potential of many cod stocks, particularly those that tend to be in poor nutritional condition, such as the northern Gulf of St. Lawrence stock (Lambert \& Dutil 1997).

Suppression of reproduction in Smith Sound cod was most common in the 40 to $49 \mathrm{~cm}$ size class. It is interesting that no difference in condition indices existed between reproductive and non-reproductive fish in that particular size range. Because smaller fish tend to invest proportionally less of their body mass in gamete production, it may be less likely that maturing fish and fish with suppressed reproduction will show differences in condition. Fish in the 40 to $49 \mathrm{~cm}$ size range are likely to be ripening for the first time (i.e. attempting to mature), suggesting that the ripening process in recruit-spawners may be more easily interrupted than in repeat-spawners. Ramsay \& Witthames (1996) reported that interruptions in the ripening process were common for recruiting sole Solea solea. Walsh \& Bowering (1981) reported that mass degeneration of early vitellogenic oocytes was common in 58 to $77 \mathrm{~cm}$ Greenland halibut Reinhardtius hippoglossoides, but quickly decreased to zero in fish larger than $93 \mathrm{~cm}$. An alternative explanation of the high proportion of non-reproductive cod in the smallest size class is that these fish were second time spawners that were unable to recover from their first spawning (Jørgensen et al. 2006). Although suppression of reproduction in Smith Sound was most common in small cod, it also occurred in all larger size classes. Therefore, in contrast to traditional estimates of the proportion of fish that mature at age, which levels off at $100 \%$, the proportion of spawning fish never reached $100 \%$ in any size class, suggesting a reduced reproductive potential for the population.

The most effective means of identifying fish with suppressed reproduction is through histological inspection of ovaries. In 1999 we used histology to verify that most of the fish macroscopically classified as spent-L were in fact undergoing mass atresia of all oocytes that had started to ripen and therefore would not have spawned (Rideout et al. 2000). In the remaining years of the study we therefore considered spent-L ovaries collected in January and February to be nonreproductive. This is also supported by the histological analyses of Walsh et al. (1986) for Flemish Cap cod. It is possible that our methodology may have been im- 
proved by histologically analysing every sample that was collected, but we believe our procedure to be sufficiently accurate to indicate the extent to which suppression of reproduction is occurring.

We have previously speculated that January or February is a good time of year to identify suppressed reproduction because mass atresia of vitellogenic oocytes is observable at this time in non-reproductive individuals (Rideout et al. 2005). In order to truly identify the optimal time of year for assessing the proportion of non-reproductive individuals within a population, however, that population should be analysed repeatedly throughout the year. To date, this has not been done for the Smith Sound aggregation. Because we sampled fish in late January or early February, 3 to 5 mo prior to spawning, it is possible that the frequency of non-reproductive fish may have been different if measured closer to the spawning season. If more females started to ripen, the overall proportion of nonreproductive fish would decrease. However, given the 6 mo period generally required to complete vitellogenesis, it is unlikely that such females would spawn. It is also possible that between the time of sampling and the start of the spawning season more females may have interrupted vitellogenesis and become nonreproductive. This would suggest that sampling closer to spawning could perhaps give a more accurate estimate of the number of non-reproductive individuals in an aggregation. However, the short lifespan of atretic oocytes (Kjesbu et al. 1991) could mean that identifying non-reproductive ovaries may be more difficult closer to the spawning season (i.e. atretic oocytes may no longer be present), resulting in an underestimation of the true number of non-reproductive individuals in the aggregation. Clearly more work is needed to determine the best time of year to evaluate the extent of suppressed reproduction within a fish population.

The fact that the 2 years with the highest suppression of reproduction were also the years in which the highest proportion of fish in Smith Sound were in the 40 to $49 \mathrm{~cm}$ size range suggests that year to year variation in the proportion of females that have suppressed gamete development will be related to the size structure of the spawning population. Years with more small fish are likely to contain a higher number of nonreproductive individuals. Exploitation typically results in a reduction in the abundance of large spawners, making the reproductive potential of the population more dependent on less productive, smaller fish (Trippel 1995). Small fish are likely to be less productive because they spawn for a shorter period of time and produce fewer egg batches, containing fewer, smaller and poorer quality eggs (Trippel 1998). In Smith Sound, the high level of suppression of reproduction in small cod suggests that increasing the reproductive potential of this population will depend heavily on enhancing the age structure to include a large proportion of larger fish. Marteinsdottir \& Thorarinsson (1998) reported that recruitment variability for Icelandic cod was reduced when a more diverse range of ages was present.

Our results show that not all fish that start to ripen successfully spawn and that the practice of assuming that all sexually mature fish spawn annually is flawed and can lead to inaccurate estimates of stock productivity. Detailed research on suppressed reproduction in other groundfish stocks is clearly needed if stock reproductive potential is to be understood and effective management strategies developed.

Acknowledgements. Jeff Hutchings, Joanne Morgan, Peter Witthames and 3 anonymous reviewers provided helpful comments on an earlier version of the manuscript. Graham Sherwood provided valuable advice on the analysis of stable isotope data. The stable isotope analyses were performed by Wendy Abdi and the staff at G. G. Hatch Isotope Laboratories at the University of Ottawa. Financial support was provided by the Natural Sciences and Engineering Research Council of Canada's Chair in Fisheries Conservation.

\section{LITERATURE CITED}

Bell JD, Lyle JM, Bulman CM, Graham KJ, Newton GM, Smith DC (1992) Spatial variation in reproduction, and occurrence of non-reproductive adults, in orange roughy, Hoplostethus atlanticus Collett (Trachichthyidae), from south-eastern Australia. J Fish Biol 40:107-122

Brattey J (1996) Biological characteristics of Atlantic cod (Gadus morhua) from three inshore areas of Western Trinity Bay, Newfoundland. Northwest Atl Fish Organ Sci Counc Res Doc 96/20

Burton MPM (1999) Notes on potential errors in estimating spawning stock biomass: determining the effects of nonparticipatory adults for some groundfish species. J Northwest Atl Fish Sci 25:1-9

Burton MPM, Idler DR (1984) The reproductive cycle in winter flounder, Pseudopleuronectes americanus (Walbaum). Can J Zool 62:2563-2567

Burton MPM, Idler DR (1987) An experimental investigation of the non-reproductive, post-mature state in winter flounder. J Fish Biol 30:643-650

Burton MPM, Penney RM, Biddiscombe S (1997) Time course of gametogenesis in Northwest Atlantic cod (Gadus morhua). Can J Fish Aquat Sci 54(Suppl 1):122-131

Dutil JD (1986) Energetic constraints and spawning interval in the anadromous Arctic charr (Salvelinus alpinus). Copeia 1986:945-955

Engelhard GH, Heino M (2005) Scale analysis suggests frequent skipping of the second reproductive season in Atlantic herring. Biol Lett 1:172-175

Fahrig L, Lilly GR, Miller DS (1993) Predator stomach as sampling tools for prey distribution: Atlantic cod (Gadus morhua) and capelin (Mallotus villosus). Can J Fish Aquat Sci 50:1541-1547

Hislop JRG, Robb AP, Gauld JA (1978) Observations on effects of feeding level on growth and reproduction in haddock, Melanogrammus aeglefinus (L.) in captivity. J Fish Biol 13:85-98 
Jørgensen C, Ernande B, Fiksen Ø, Dieckmann U (2006) The logic of skipped spawning in fish. Can J Fish Aquat Sci 63:200-211

Kennedy WA (1953) Growth, maturity, fecundity and mortality in the relatively unexploited whitefish, Coregonus clupeaformis, of Great Slave Lake. J Fish Res Board Can 10: 413-441

Kjesbu OS, Klungsøyr J, Kryvi H, Witthames PR, Greer Walker M (1991) Fecundity, atresia, and egg size of captive Atlantic cod (Gadus morhua) in relation to proximate body composition. Can J Fish Aquat Sci 48:2333-2343

Kjesbu OS, Witthames PR, Solemdal P, Greer Walker M (1998) Temporal variations in the fecundity of Arcto-Norwegian cod (Gadus morhua) in response to natural changes in food and temperature. J Sea Res 40:303-321

Lambert Y, Dutil JD (1997) Condition and energy reserves of Atlantic cod (Gadus morhua) during the collapse of the northern Gulf of St. Lawrence stock. Can J Fish Aquat Sci 54:2388-2400

Lambert Y, Dutil JD (2000) Energetic consequences of reproduction in Atlantic cod (Gadus morhua) in relation to spawning level of somatic energy reserves. Can J Fish Aquat Sci 57:815-825

Lilly GR (1991) Interannual variability in predation by cod (Gadus morhua) on capelin (Mallotus villosus) and other prey off southern Labrador and northeastern Newfoundland. ICES Mar Sci Symp 193:133-146

Maddock DM, Burton MPM (1994) Some effects of starvation on the lipid and skeletal muscle layers of the winter flounder, Pleuronectes americanus. Can J Zool 72:1672-1679

Marshall CT, Kjesbu OS, Yaragina NA, Solemdal P, Ulltang Ø (1998) Is spawner biomass a sensitive measure of the reproductive and recruitment potential of Northeast Arctic cod? Can J Fish Aquat Sci 55:1766-1783

Marshall CT, O'Brien L, Tomkiewicz J, Köster FW and 9 others (2003) Developing alternative indices of reproductive potential for use in fisheries management: case studies for stocks spanning an information gradient. J Northwest Atl Fish Sci 33:161-190

Marteinsdottir G, Thorarinsson K (1998) Improving the stockrecruitment relationship in Icelandic cod (Gadus morhua) by including age diversity of spawners. Can J Fish Aquat Sci 55:1372-1377

May AW (1967) Fecundity of Atlantic cod. J Fish Res Board Can 24:1531-1551

Oganesyan SA (1993) Periodicity of the Barents Sea cod reproduction. Int Counc Explor Sea Comm Meet Pap G:64

Ozhigin VK, Tretyak VL, Yaragina NA, Ivshin VA (1994) Dependence of the Barents Sea cod growth upon conditions of their feeding on capelin and water temperature. Int Counc Explor Sea Comm Meet Pap G:32

Ramsay K, Witthames P (1996) Using oocyte size to assess seasonal ovarian development in Solea solea (L.). J Sea Res 36:275-283

Rideout RM, Burton MPM, Rose GA (2000) Observations on mass atresia and skipped spawning in northern Atlantic cod, from Smith Sound, Newfoundland. J Fish Biol 57: $1429-1440$

Editorial responsibility: Howard I. Browman (Associate Editor-in-Chief) Storebø, Norway
Rideout RM, Rose GA, Burton MPM (2005) Skipped spawning in female iteroparous fishes. Fish Fish 6:50-72

Rijnsdorp AD (1990) The mechanism of energy allocation over reproduction and somatic growth in female North Sea plaice, Pleuronectes platessa L. Neth J Sea Res 25: 279-290

Rose GA (2003) Monitoring coastal northern cod: towards an optimal survey of Smith Sound, Newfoundland. ICES J Mar Sci 60:453-462

Rose GA, O'Driscoll RL (2002) Capelin are good for cod: can the northern stock rebuild without them? ICES J Mar Sci 59:1018-1026

Sherwood GD, Rose GA (2005) Stable isotope analysis of some representative fish and invertebrates of the Newfoundland and Labrador continental shelf food web. Estuar Coast Shelf Sci 63:537-549

Sherwood GD, Rose GA (in press) Ontogeny of optimal foraging by Atlantic cod (Gadus morhua) in an exploited ecosystem. Ecol Appl

Shirokova MY (1969) The sexual maturation rate of the generations of Baltic cod taken from 1961-63. Tr Atl Nauchno-Issled Inst Rybn Khoz Okeanogr 21:37-44

Steinarsson BÆ, Stefánsson G (1991) An attempt to explain cod growth variability. ICES Comm Meet Pap G:42

Steinarsson BÆ, Stefánsson G (1996) Factors affecting cod growth in Icelandic waters and the resulting effect on potential yield of cod. ICES Comm Meet Pap G:32

Taggart CT, Anderson J, Bishop C, Colbourne E and 7 others (1994) Overview of cod stocks, biology, and environment in the Northwest Atlantic region of Newfoundland, with emphasis on northern cod. ICES Mar Sci Symp 198:140-157

Templeman W, Hodder VM, Wells R (1978) Sexual maturity and spawning in haddock, Melanogrammus aeglefinus, of the Southern Grand Bank. Int Comm Northwest Atl Fish Res Bull 13:53-65

Trippel EA (1995) Age at maturity as a stress indicator in fisheries. BioScience 45:759-771

Trippel EA (1998) Egg size and viability and seasonal offspring production of young Atlantic cod. Trans Am Fish Soc 127:339-359

Walsh SJ, Bowering WR (1981) Histological and visual observations on oogenesis and sexual maturity in Greenland halibut off northern Labrador. NAFO Scientific Council Studies 1:71-75

Walsh SJ, Wells R, Brennan S (1986) Histological and visual observations on oogenesis and sexual maturity of Flemish Cap female cod. Northwest Atl Fish Organ Sci Counc Res Doc 86/111

Woodhead AD, Woodhead PMJ (1965) Seasonal changes in the physiology of Barents Sea cod, Gadus morhua L., in relation to its environment. 1. Endocrine changes particulary affecting migration and maturation. Int Comm Northwest Atl Fish Spec Publ 6:691-715

Yaragina NA, Marshall CT (2000) Trophic influences on interannual and seasonal variation in the liver condition index of Northeast Arctic cod (Gadus morhua). ICES J Mar Sci 57:42-55

Submitted: June 16, 2005; Accepted: January 6, 2006 Proofs received from author(s): August 4, 2006 